\title{
John O'Keeffe, The Masses of Seán and Peadar Ó Riada: Explorations in Vernacular Chant
}

\section{Erick Falc'her-Poyroux}

\section{(2) OpenEdition}

1 Journals

\section{Édition électronique}

URL : https://journals.openedition.org/etudesirlandaises/8709

DOI : 10.4000/etudesirlandaises.8709

ISSN : 2259-8863

\section{Éditeur}

Presses universitaires de Caen

\section{Édition imprimée}

Date de publication : 31 décembre 2019

Pagination : 164-165

ISBN : 978-2-84133-964-8

ISSN : 0183-973X

Référence électronique

Erick Falc'her-Poyroux, « John O'Keeffe, The Masses of Seán and Peadar Ó Riada: Explorations in Vernacular Chant », Études irlandaises [En ligne], 44-2 | 2019, mis en ligne le 06 mai 2020, consulté le 15 novembre 2022. URL : http://journals.openedition.org/etudesirlandaises/8709; DOI : https://doi.org/ 10.4000/etudesirlandaises.8709

\section{(c) (i) (2) (2)}

Creative Commons - Attribution - Pas d'Utilisation Commerciale - Partage dans les Mêmes Conditions 4.0 International - CC BY-NC-SA 4.0

https://creativecommons.org/licenses/by-nc-sa/4.0/ 
that Paisley said it was his favourite photograph of himself. Steafán Hanvey's description of how the photograph was taken also highlights Paisley's capacity for wit, something which many would have doubted during the height of the Troubles, when he repeated his mantra of "No Surrender" and was referred to as "Dr. No" in the media for his fiery outbursts and intransigence on potential co-operation with Republicans.

While this book is ostensibly a personal reflection on a selection of photographs taken during the Troubles, it could also be described as an homage by Steafán to his father, whom he refers to as "my fathographer" (p. 15) in the introduction. Later on, he refers to his father affectionately as "my da: a memorymaking middleman, assessor from The Ministry Of Lost Causes" (p. 26), and "my da, the master image builder" (p. 73). In the introduction, we learn a little of what prompted the book, but it would also have been nice to learn something about the selection process used to pick the photographs that appear in the book. What were the criteria and was there any subject matter that was deemed ineligible for whatever reason? Many of Bobbie Hanvey's photographs taken during the Troubles are now housed in an American university library. There are over 50,000 negatives in the Bobbie Hanvey Photographic Archives in the John J. Burns Library in Boston College. They span the period from the 1970s through to circa 2007. Given the perfect marriage of photograph and poem in this book and the sheer volume of images to pick from, it is clear that another book (or more) of photographs and poems is called for.

Oliver O’HANLON

\section{John O'Keeffe, The Masses of Seán and Peadar Ó Riada: Explorations in Vernacular Chant, Cork, Cork University Press, 2017, 298 p. + audio CD.}

Seán Ó Riada once expressed his strong attachment to his country, after a few months spent in Paris, stating that he would "rather be breaking stones in Ireland than be the richest man living in Europe". One of the main elements of this attachment was certainly his love of the Irish language: after his nomination at University College Cork in 1964, he decided to settle with his family in the Múscraí Gaeltacht area of Cúil Aodha (Coolea) in West Cork, where his mother originated. This is also where he composed his two masses and where his son Peadar grew up.

This book studies the two masses composed by Seán Ó Riada (1931-1971) as well as the mass composed by his son Peadar Ó Riada (born 1954) and was appropriately published fifty years after the Vatican II reforms on music, and in particular the Musicam Sacram of March 1967, which radically changed the way liturgical music could be composed for the Roman Catholic mass, by giving more freedom to composers on the language they could use for its celebration and consequently developing the participation of the congregation. 
John O'Keeffe, the author of the book, is Director of Sacred Music at the Department of Theology, St. Patrick's College, Maynooth, and Director of Choral Groups. In the seven chapters of the work, he proposes a very technical and thorough study of the three masses in Irish with many score extracts giving detailed and sometimes lengthy musical examples, accompanied by their lyrics. The book also includes an audio CD with complete recordings of the masses, as well as an impressive bibliography and a general index.

The musical environment where Seán Ó Riada's masses were composed, in Coolea, County Cork, constitutes the first approach of the volume, while the second chapter describes the intimate relationship between music and lyrics, in a historical context as well as in the geographical context of South West Ireland. The following two chapters analyse respectively Seán Ó Riada's first mass - and the first ever in Irish Gaelic - Ceol an Aifrinn [Music for mass], as well as his second opus, Aifreann 2 [Mass 2], both composed for the Benedictines at Glenstal Abbey, County Limerick, while chapters 5 and 6 examine in detail Peadar Ó Riada's own composition Aifreann Eoin na Croise [Mass for St. John of the Cross], composed for the Carmelite community of Dublin.

One of the most important features of this book, apart from the fact that no lengthy study of these musical opuses had previously been published, resides in the way it convincingly demonstrates a strong link between the composers and their environment, be it linguistic, musical or historical. Obviously, previous knowledge of the Catholic liturgy, as well as solid musical theory knowledge, will be necessary to fully appreciate the extent of the author's demonstration, but most chapters can be approached candidly and will display what the author probably had in mind when writing them: to testify to the huge musical legacy of the Ó Riadas, as well as their indisputable attachment to their country and its Catholic background.

Erick FALC'HER-POYROUX

\section{Marnie Hay, Na Fianna Éireann and the Irish Revolution, 1909-1923: Scouting for Rebels, Manchester, Manchester University Press, 2019, 288 p.}

By the late $19^{\text {th }}$ century, the Gaelic Cultural Revival had popularised early Irish myths and the heroic tales of Fionn Mac Cumhaill, the boy hero and his band of young warriors, the Fianna. "Fenians", an anglicised version, had become an umbrella term for an international network of Irish militant separatists, but they evidently live on (in both guises?) in Ireland's national anthem, Amhrán na bhFiann. When Constance Markievicz and Bulmer Hobson founded a nationalist uniformed youth group in Dublin in 1909, firmly intended to counteract the pro-British Baden Powell Boy Scouts, they logically named it Na Fianna Éireann. It was to be the nucleus of a future Irish army. Training in military drill commenced immediately, and Con Colbert (one of the sixteen executed in 1916, aged twenty-eight) was their first 